\title{
RESEARCHPAPER
}

\section{Effect of organic manure, vermicompost and neemcake on growth, yield and profitability of turmeric (Curcuma longa L.) variety- Megha Turmeric-1}

\author{
I. SARMA, M. PHUKON AND ROOPA BORGOHAIN
}

Krishi Vigyan Kendra (A.A.U.), JORHAT (ASSAM) INDIA

Email : irasarma@gmail.com

Article Info :Received : 29.07.2015; Revised : 19.08.2015; Accepted : 05.09.2015

A field experiment was conducted during 2012-2013 at farmer's field of Jorhat district to investigate the effect of different organic nutrients on growth, yield and economics of turmeric cultivation. The experiment was laid out in Randomized Block Design with four treatments and five replications. Application of different combinations of organic manure, vermicompost and neemcake influenced the growth and yield of turmeric variety Megha Turmeric-1. The results revealed that the combined applications of FYM + vermicompost + neemcake i.e. $\mathrm{T}_{4}$ increased plant height, number of fingers, girth of rhizome, weight of rhizome and rhizome yield. While minimum of these were observed in the absolute control i.e. $\mathrm{T}_{1}$. Highest rhizome yield $\left(20.48 \mathrm{t} \mathrm{ha}^{-1}\right)$ with maximum benefit- cost ratio (3.6) was obtained in the treatment combination $\mathrm{T}_{4}$ and the lowest yield $\left(12.50 \mathrm{t} \mathrm{ha}^{-1}\right)$ was obtained in the treatment $\mathrm{T}_{1}$ with minimum benefit- cost ratio (3.1).

Key words : Organic, Turmeric, Vermicompost, FYM, Neemcake

How to cite this paper : Sarma, I., Phukon, M. and Borgohain, Roopa (2015). Effect of organic manure, vermicompost and neemcake on growth, yield and profitability of turmeric (Curcuma longa L.) variety- Megha Turmeric-1. Asian J. Bio. Sci., 10 (2) : $133-137$. 